\title{
Review Essay \\ The Life and Ideas of Ol'gerd Ipolyt Bochkovs'kyi
}

\author{
Piotr J. Wróbel \\ University of Toronto
}

Ol'gerd Ipolyt Bochkovs'kyi: Vybrani pratsi ta dokumenty [Ol'gerd Ipolyt Bochkovs'kyi: Selected Works and Documents]. Compiled by Olia Hnatiuk and Myroslav Chekh, Zhurnal "Ukraina Moderna" / Vydavnytstvo "Dukh i Litera," 2018-19. 3 vols. Ukraina. Ievropa: 1921-1939 [Ukraine. Europe: 1921-1939]. 704 pp. (vol. 1), 976 pp. (vol. 2), 852 pp. (vol. 3). Illustrations. Tables. Indexes. $\$ 44.95$ (per vol.), cloth.

Throughout most of human history, the idea of nation was an alien one. 1 The word first appeared in the Middle Ages, but it initially meant something else. Modern nations started developing in the late eighteenth century, but this phenomenon evolved in different places, at varying speeds, and, even, differently in form. In the twentieth century, nations became a strong and unifying force as the primary actors of political history: many people believed that only this type of social organization could guarantee societal well-being. Today, however, some Western societies have already achieved a postnational stage. Many people consider this spread of nations and national identity to be just another stage in human evolution, and therefore, they reject these ideas as pivotal to society.

The history and sociology of nations provoke, and have always provoked, lively debates, and they have led to the production of many scholarly works. In Eastern Europe, however, particularly in the former Soviet Union, the pace of the formation of nations was decreased. Since this process was engineered in a Soviet way, the research on nations was more controlled and ideologically conditioned than it was in the West. Ukraine, a striking example of these phenomena in action, became the scene of intense academic discussion regarding nations after the fall of the Soviet Union in the 1990s. Politicians, scholars, and ordinary people returned to topics neglected and forbidden under Communist rule. They started reading forgotten authors that had been censored or disposed of by the authoritarian regime. Ukrainian publishers issued dozens of volumes of Mykhailo Hrushevs'kyi, Dmytro Dontsov, V"iacheslav Lypyns'kyi, and Mykhailo Drahomanov. One of these shunned authors, Ol'gerd Ipolyt Bochkovs'kyi, was mostly unknown. And 
even though short entries and text fragments about him had appeared in various encyclopedias and general works, it was not until the twenty-first century that the majority of his publications were recognized (Hyrych 44; Rudnytsky 365; Kanevs'ka 391-92)

In 2009, Iryna Kanevs'ka defended a candidate dissertation on the topic of Bochkovs'kyi at the Institute of Ukrainian Archaeography and Source Studies of the National Academy of Sciences of Ukraine in Kyiv. Later, she published numerous works on the scholar and wrote a lengthy biographic essay about him. Volume 1 of the publication under review opens with this essay (1: 11-98), coupled with a short introduction by Olia Hnatiuk and Myroslav Chekh (Mirosław Czech; 1: 99-104). Kanevs'ka shows how Bochkovs'kyi's extraordinary life influenced his ideas. He was born in 1885 in eastern Ukraine, in the village of Dolynska in the Kherson gubernia, to a Polish Catholic family. His father, Apollo Boczkowski, worked at the local railway station as an engineer. His mother, Anna Rajecka, had a PolishLithuanian background. Bochkovs'kyi's twin brother, Mieczysław, died in infancy, but his younger brother, Tadeusz, later became a Catholic priest. In 1903, young Ol'gerd, having graduated from provincial schools, moved to St. Petersburg to study at the Forestry Institute. There, he participated in the 1905 Revolution as a member of student and social-democratic organizations. In the fall of that same year, he left Russia. His dream was to go to Paris, which in his opinion was "a Mecca for revolutionaries." However, he landed in Kraków and several months later, in Prague, where he spent the rest of his life (Kanevs'ka 393). ${ }^{1}$

Initially, Bochkovs'kyi knew very little about Czechs and believed that he had come to Austria (1: 17). In Prague, he socialized mostly with Poles, and he studied sociology at the Czech Charles-Ferdinand University between 1906 and 1909. Politically, he was involved in anti-Russian activities and considered Europe to be his spiritual and intellectual motherland. Over several years, he moved closer to Ukrainian emigrants and eventually changed his nationality and the spelling of his name. (As a side note, it is unfortunate that Kanevs'ka and other biographers do not adequately explain this national-identity conversion.) In Prague, Bochkovs'kyi joined the movement against the death penalty and published extensively in that field (Stryjek 195). In socializing with abolitionists, he met Tomáš Garrigue Masaryk. The two became friends, and soon Masaryk became a teacher, a colleague, and someone whom Bochkovs'kyi admired. Bochkovs'kyi worked for several periodicals as a journalist and a Russian specialist. A major one was Slovanský Přehled (Slavonic Review [Prague]), where, in 1908, he

${ }^{1}$ All translations in the review are mine.

(C) 2020 East/West: Journal of Ukrainian Studies (ewjus.com) ISSN 2292-7956

Volume VII, No. 1 (2020) 
published his first article, "Ruské politické strany a skupiny" ("Russian Political Parties and Groups"; 1: 658). From 1909 to 1911, his first scholarly monograph (which came out in 1910 as a separate book), Ukrajinská otázka (The Ukrainian Question), was released in instalments (1: 24, 656, 658). Simultaneously, in 1911, in St. Petersburg, he published (in Russian) Iz istorii vozrozhdeniia ukrainskogo naroda (From the History of the Revival of the Ukrainian People). At the time, he was still known as Hipolit Boczkowski. Influenced by Masaryk's epochal Česká otázka (The Czech Question, 1895), Bochkovs'kyi wanted to incite change. And according to him, the Ukrainian problem was a "terra incognita" even to the Slavic people (1: 25). In 1909, he became a foreign correspondent for Rada (Council), the first Ukrainianlanguage daily published in Kyiv (1906-14), even though at that point, he still described himself as a non-Ukrainian (1: 34).

After the outbreak of World War I, the Austrian authorities arrested the scholar as a Russian citizen. Released after Masaryk's intervention, Bochkovs'kyi was interned outside of Prague but continued his scholarly activities. He joined the Union for the Liberation of Ukraine (SVU) and published pieces in its Vistnyk Soiuza vyzvolennia Ukrainy (Herald of the Union for the Liberation of Ukraine [Vienna]). Those internment years were very fruitful, as he authored numerous articles and several brochures and books. In 1915, a hardcover collection of his scholarly articles appeared, entitled Ukrajina a ukrajinská otázka (s přehlednou národopisnou mapou Ukrajiny) (Ukraine and the Ukrainian Question [with a Clear Ethnographic Map of Ukraine]; 1: 656). It argued that an independent Ukrainian state would be necessary for a peaceful European equilibrium. This was Bochkovs'kyi's last book originally written in a language other than Ukrainian (Stryjek 195). In 1916, he published two more works, which are presented in volume 1 of the collection under review. The first one, Ponevoleni narody tsars'koi imperii: Ikh natsional'ne vidrodzhennia ta avtonomichni priamuvannia (do natsional'noi spravy $v$ Rosii) ${ }^{2}$ (Subjugated Peoples of the Tsarist Empire: Their National Revivals and Strivings for Autonomy [Regarding the National Matter in Russia]; 1: 123-376, 656), according to its author, has a "general informative character" and is "directed against the Tsarist Empire." And he aims to explain that phrase, calling Russia a "'prison of nations'" (1: 125). The book offers reviews of the national histories and movements of a number of nationalities living in the Russian Empire: Finns, Poles, Belarusians, Jews, Romanians, Lithuanians, Latvians, Estonians, Armenians, Georgians, Muslims and Tatars, and other inorodtsy.

2 The spelling of the title in the original work reflects the orthography used by Bochkovs'kyi: "vidrodzhenie" and "priamuvania" (Bochkovs'kyi, Ponevoleni narody). 
There are no separate chapters on Ukrainians and Germans. The author believed that both of these nations had been well described in publications in their respective languages (1: 127). The text opens with an extended introduction that offers basic statistical data and analyzes Russian historical and contemporary governmental policies regarding national minorities. It also discusses how both legal and illegal political parties in Russia presented their plans and views in this arena. Bochkovs'kyi believed that the Russian motherland needed (at least) decentralization and federalization, if not division into several independent states. Otherwise, it presented a danger to Europe, even under a liberal government (1: 173).

Bochkovs'kyi considered Polish and Finnish national issues to be key areas of study for dealing with similar questions in Russia $(1: 145,154)$. He admired the Finns with their impressive educational and cultural achievements. He also took note of their rational and non-violent methods in their strivings for national emancipation. His second book, which was published in Ukrainian in 1916 and is contained in this collection (as Finliandiia ta finliands'ke pytannia [Finland and the Finnish Question; 1: 377468, 656]), ${ }^{3}$ advances his first arguments on Finland. Aside from Bochkovs'kyi's Ukrainian studies, this work became his most thorough analysis of the national problem concept (Stryjek 195). Bochkovs'kyi divided the Poles and Finns into a "historical nation" and a "non-historical nation," respectively. The former used to have a state and the latter did not. Bochkovs'kyi believed that the Finns could be an example for other, similar nationalities of the Russian Empire, demonstrating how they changed in the nineteenth century. They started as an "amorphic ethnographic mass incapable of having an independent cultural and national life and, even more, of establishing their own state and gaining for themselves political sovereignty and independence" (1: 378).

Volume 1 also presents another book by Bochkovs'kyi-Natsional'na sprava (statti pro natsional'ne pytannia $v$ zv"iazku z suchasnoiu viinoiu) ${ }^{4}$ (The National Matter [Articles about the National Question in Connection with the Present-Day War]; 1: 469-654, 656). Although it was written in 1917, the turmoil of the final years of World War I caused its publication to be put off until 1918. This work addresses Bochkovs'kyi's national theory and his concept of natsiolohiia 'nation study' (which is described further below). Aptly, this book marks the end of the first period of Bochkovs'kyi's life, a time

\footnotetext{
3 The spelling of the title in the original work, again, is slightly different: "pytannie" (Bochkovs'kyi, Finliandiia).

4 In the title of the original work, we encounter "stati," "pytannie," and "zviazku" (Bochkovs'kyi, Natsional'na sprava).
} 
when he formulated ideas that he would later elaborate on, mainly during the most productive period of his life, from 1923 until the mid-1930s (Stryjek 195-96; Hvat').

After the fall of the Habsburg Empire, Bochkovs'kyi returned to Prague, and joined the diplomatic mission of the Ukrainian National Republic (191923). He started teaching at multiple institutions-first, the Ukrainian Free University (UVU) and, subsequently, the Ukrainian Husbandry Academy (UHAK) and the Ukrainian Technical and Husbandry Institute (UTHI). These institutions were established as part of the Czechoslovak government's efforts to help deal with a sizable emigration from the Russian Empire. However, they struggled for survival on account of diminishing financial support from Prague. In 1935, the UHAK closed. That same year, Bochkovs'kyi became a full member of the most prominent Ukrainian scholarly institution, the Shevchenko Scientific Society (NTSh), in Lviv (Stryjek 196-97).

In his teaching and research, Bochkovs'kyi concentrated on the sociology of nations and published prolifically in that field. His habilitation thesis was developed and broadened, and it became a large monograph, entitled T. G. Masaryk: Natsional'na problema ta ukrains'ke pytannia (sproba kharakterystyky ta interpretatsii) (T. G. Masaryk: The National Problem and the Ukrainian Question [An Attempt to Characterize and Interpret]; 2: 9-284; 1: 657). This work came out in 1930. It is included at the beginning of volume 2 of the collection under review. Two years later, Bochkovs'kyi published another great work-Borot'ba narodiv za natsional'ne vyzvolennia: Natsiolohichni narysy (The Struggle of Nations for National Freedom: Sketches from Nation Studies; 2: 285-602; 1: 657). Both this piece and Vstup do natsiolohii (Introduction to Nation Study; 2: 603-940; 1: 657) round out the volume. The latter is the most important scholarly achievement in the collection. Initially, it was a German-language compilation of several of Bochkovs'kyi's theoretical works, which came out in Prague in 1936 under the title Grundlagen des Nationalproblems: Einführung in die Natiologie (Basics of the National Problem: Introduction to Nation Study; 1: 657). Its Ukrainian version, edited and amended, appeared for the first time in Munich in 1991-92, published by the UVU.

These works helped establish a new branch of sociology called natsiolohiia-a discipline that examines the formation of nations. It was influenced by multiple sources: Masaryk, the Czech national emancipation, the German theory of a "state of law," Austro-Marxism, and Habsburg policies regarding national minorities. Bochkovs'kyi tried to apply Western and central European theories to the Eastern European and Ukrainian cases. He rejected the ideologies of nation-building that were rooted in ideas of race 
and was skeptical about the importance of a national language. For him, religion, history, and, especially, "national culture" were crucial in this development, as were commonalities within the emotions and will of the people. Besides expressing the notion of two divisions (mentioned above)"historical," having a state, and "non-historical," never having had a stateBochkovs'kyi sometimes applied the concept of a "half-historical" nation. This refers to a nation that used to have a state a long time ago. In Bochkovs'kyi's understanding, "national awakening" and the establishment of a "national culture" constitute the first phase of a process leading to national emancipation. Here, he emphasized the importance of the Reformation and of national literatures written in native languages. He called the second phase "economic," that is, when members of an emerging nation dominate the labour forces of local economies. The third and last phase, called the "self-determination," or "political," phase, starts when nations can form their states or, at least, achieve significant autonomy (Stryjek 191-217).

The above concept closely resembles the well-known theory of another scholar from Prague-Miroslav Hroch. In the 1960s, Hroch also defined three stages of national creation: phase $\mathrm{A}$-the cultural, historical, and linguistic research of the first activists; phase $\mathrm{B}$-drawing in as many individuals as possible to the project of national creation; and phase $\mathrm{C}$ - when a majority of the local population creates a mass movement formulating national demands. Some believe that Bochkovs'kyi's theory was also a precursor to Benedict Anderson's opinions on the ideas of a nation and of nationalism (Hyrych 47).

Bochkovs'kyi considered nation to be a "natural organizational form of the human race," but he was Eurocentric in these beliefs. In his view, European nations, beginning with modern England, have achieved the highest stage of development. He studied Austro-Marxists and saw an essential link between national development, democracy, and socialism. He saw that only the democratic order was able to involve a maximum number of individuals in everyday national activities. He claimed that without democracy and political freedom, including the emancipation of workers and peasants, the establishment of a modern nation was impossible. However, "historical" nations had been created, according to him, in a "mechanical" way, from above, mostly by state institutions. "Non-historical" nations, he continued, were formed in a more "organic" way, from below. They produced their intelligentsia and, in the twentieth century, reached the same developmental stage as "historical" nations (Stryjek 208-17).

In 1933, Bochkovs'kyi headed the so-called Famine Committee in Prague to help the starving people of Ukraine. This required his intense participation. He ran a Czech-language information bulletin called Hlad na 
Ukrajině—La famine en Ukraine (Hunger in Ukraine [Prague]) and published numerous brochures and articles in various periodicals. The most famous among them was an open letter to Édouard Herriot (1: 105-08, 678), who thrice served as premier of France, was the long-time president of the Chamber of Deputies, and was the mayor of Lyon. In August and September 1933, at the peak of the Stalin-induced starvation in Ukraine, Herriot visited the country. He denied the famine and compared Soviet Ukraine to a "garden in full bloom" (1: 112). Bochkovs'kyi, in a letter published in September 1933, expressed his amazement about the fact that the French politician, well known for his defence of freedom, had become an "accomplice of Moscow in its bloody pogrom of Ukraine" (1: 108). Herriot shrugged off critics of his proSoviet propaganda as "fools or Hitler's agents" (1: 110). The scholar responded with another angry article (1: 109-16, 678), and finally, disappointed and bitter, he wrote "Bezkhrebetna Evropa (Europa Invertebrata)" ("Spineless Europe [Europa Invertebrata]"; 1: 671). He was devastated that Europe had lost its moral standards and that the same people who had defended Alfred Dreyfus had now become "sovietophiles" (1: 11721).

The editors of the collection under review considered these three articles to be very important. They amended them, added a short introduction, "Ol'gerd Ipolyt Bochkovs'kyi: 'J'accuse!' ('Ia zvynuvachuiu!')" (“Ol'gerd Ipolyt Bochkovs'kyi: 'J'accuse!' ['I Accuse!']"; 1: 99-104), and published the grouping at the beginning of the first volume, just after the biographic essay. A selection of Bochkovs'kyi's other articles (some ninety of them), taken from various periodicals, are presented in volume 3 . These works are divided into nine sections: "Problemy natsiietvorennia" ("Problems of Nation-Building"; 3: 254-339), "Ukrains'ki natsiietvorchi protsesy" ("Ukrainian Nation-Building Processes"; 3: 340-435), "Natsiietvorchi protsesy v Zakhidnii Evropi" ("Nation-Building Processes in Western Europe"; 3: 436-531), "Tvorennia modernoi ches'koi natsii" ("The Formation of the Modern Czech Nation"; 3: 532-93), "Ches'ko-ukrains'ki vzaiemyny" ("Czech-Ukrainian Relations"; 3: 594-628), "Ob"iednana Evropa" ("United Europe"; 3: 629-71), "Sotsializm, marksyzm i bil'shovyzm" ("Socialism, Marxism, and Bolshevism"; 3: 672-731), "Demokratiia u kryzi" ("Democracy in Crisis"; 3: 732-88), and "Dodatok: Retsenzii ta polemiky" ("Appendix: Reviews and Polemical Articles"; 3: 789-831).

In 1936, Bochkovs'kyi visited Canada and the United States on the invitation of Ukrainian Canadians. There, he delivered a series of lectures and raised a substantial amount of money for Ukrainian organizations in Europe. He had another successful trip-to Paris, in 1937, during the Exposition Internationale des Arts et Techniques dans la Vie Moderne. He was supposed 
to visit Canada again in 1938, but unfortunately, he never made it. His health was deteriorating rapidly, and he was overwhelmed by the collapse of Czechoslovakia and the rise of the Third Reich. He decided that his theories, which were linked to the development of democracy, had fallen apart on account of the chaos around him: "And my subject is so scholarly bankrupted on account of the recent events in Europe that it is unclear how to teach it..." (1: 97). He died a broken man on 9 November 1939, in Prague.

The publication of this collection is a significant achievement: it brings a forgotten but important social scientist back into the scholarly fold. Ukrainian national thought is too often linked with right-wing politics. Bochkovs'kyi countered this when he formulated a "democratic version of Ukrainian nationalism" and tried to place those ideas in the context of European democracy (Hyrych 45). The editors of this collection, Hnatiuk and Chekh, faced a difficult task: The list of Bochkovs'kyi's publications contains over five hundred entries (Kanevs'ka 393). It certainly was not easy to select the most essential and representative pieces. Luckily, however, these editors are experienced literati. Hnatiuk, a professor at the Institute of Slavic Studies of the Polish Academy of Sciences, has produced several award-winning books, including the best-selling Odwaga i strach (Courage and Fear). Chekh, a graduate of the University of Warsaw History Department, is an editor, journalist, and former deputy of Polish parliament. As such, their curation has ensured that this collection of works is a "must-own" for anyone who is interested in Eastern European national questions.

\section{Works Cited}

Bochkovs'kyi, Ipolyt. Finliandiia ta finliands'ke pytannie. Soiuz vyzvolennia Ukrainy, 1916. Diasporiana.org.ua, http://diasporiana.org.ua/wpcontent/uploads/books/14937/file.pdf. Accessed 16 Mar. 2020.

---. Natsional'na sprava (stati pro natsional'ne pytannie v zviazku z suchasnoiu viinoiu). Vistnyk polityky, literatury i zhyttia, 1918. Diasporiana.org.ua, http://diasporiana.org.ua/wp-content/uploads/books/155/file.pdf. Accessed 16 Mar. 2020.

---. Ponevoleni narody tsars'koi imperii: Ikh natsional'ne vidrodzhenie ta avtonomichni priamuvania (do natsional'noi spravy $v$ Rosii). Politychna biblioteka Mykoly Zalizniaka, 1916. Diasporiana.org.ua, http://diasporiana.org.ua/wpcontent/uploads/books/14936/file.pdf. Accessed 16 Mar. 2020.

Hnatiuk, Ola, Odwaga i strach. Wydawnictwo KEW, 2015. 
Hvat', Ivan. "Prozrinnia Ol'herda Bochkovs'koho: Ukrains'kyi politoloh-vizioner utvorennia ob"iednanoi Ievropy." Den' [Kyiv], 18 Dec. 2009, 12:00 a.m., https://day.kyiv.ua/uk/article/ukrayina-incognita/prozrinnya-olgerdabochkovskogo. Accessed 9 Mar. 2020.

Hyrych, Ihor. "Tvorchist' natsioloha Ol'herda Bochkovs'koho ta sprava vydannia ioho spadshchyny." Ukrains'ka biohrafistyka: Zbirnyk naukovykh prats' Instytutu biohrafichnykh doslidzhen' [Kyiv], vol. 15, 2017, pp. 43-57.

Kanevs'ka, Iryna. “Ol'herd Ipolyt Bochkovs'kyi (1885-1939)—ches'ko-ukrains'kyi naukovets', publitsyst, hromads'ko-politychnyi diiach." Naukovi zapysky: Zbirnyk prats' molodykh vchenykh ta aspirantiv [Kyiv], vol. 21, 2010, pp. 391-411. Naukova elektronna biblioteka periodychnykh vydan' NAN Ukrainy, http://dspace.nbuv.gov.ua/bitstream/handle/123456789/71944/24Kanevska.pdf?sequence=1. Accessed 9 Mar. 2020.

Rudnytsky, Ivan L. "Observations on the Problem of 'Historical' and 'Non-historical' Nations." Harvard Ukrainian Studies, vol. 5, no. 3, September 1981, pp. 358-68.

Stryjek, Tomasz. Ukraińska idea narodowa okresu międzywojennego: Analiza wybranych koncepcji. Fundacja na Rzecz Nauki Polski, 2000. Seria Humanistyczna. 